\title{
Difference in The Level of Workshop Safety Practices among Students Across Gender
}

Siti Aishah Mohd Yusoff, Nurul Nazirah Mohd Imam Ma'arof, Mohd Firdaus Mustaffa Kamal

To Link this Article: http://dx.doi.org/10.6007/IJARBSS/v11-i10/11336

DOI:10.6007/IJARBSS/v11-i10/11336

Received: 08 August 2021, Revised: 02 September 2021, Accepted: 24 September 2021

Published Online: 06 October 2021

In-Text Citation: (Yusoff et al., 2021)

To Cite this Article: Yusoff, S. A. M., Ma'arof, N. N. M. I., \& Kamal, M. F. M. (2021). Difference in The Level of Workshop Safety Practices among Students Across Gender. International Journal of Academic Research in Business and Social Sciences, 11(10), 418-425.

Copyright: (c) 2021 The Author(s)

Published by Human Resource Management Academic Research Society (www.hrmars.com)

This article is published under the Creative Commons Attribution (CC BY 4.0) license. Anyone may reproduce, distribute, translate and create derivative works of this article (for both commercial and non-commercial purposes), subject to full attribution to the original publication and authors. The full terms of this license may be seen at: http://creativecommons.org/licences/by/4.0/legalcode

Vol. 11, No. 10, 2021, Pg. 418 - 425

Full Terms \& Conditions of access and use can be found at http://hrmars.com/index.php/pages/detail/publication-ethics 


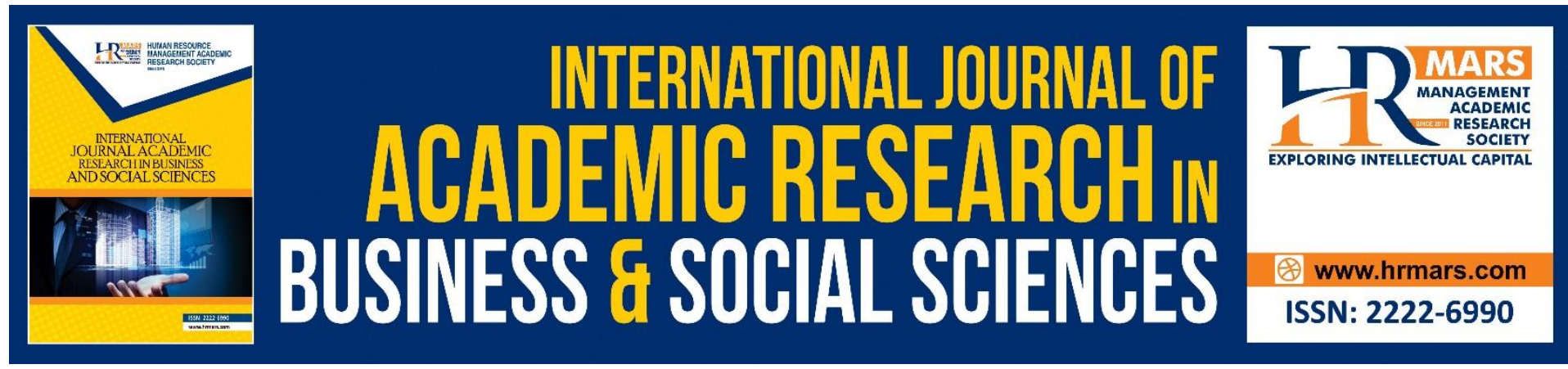

\title{
Difference in The Level of Workshop Safety Practices among Students Across Gender
}

\author{
Siti Aishah Mohd Yusoff, Nurul Nazirah Mohd Imam Ma'arof, \\ Mohd Firdaus Mustaffa Kamal
}

Faculty of Technical and Vocational, Universiti Pendidikan Sultan Idris, 35900 Tanjung

Malim, Perak, Malaysia

\begin{abstract}
The safety factor is important following its significance to the individuals performing the work, the equipment used, and the work environment. The 2015 statistical report by the National Institute of Safety and Health (NIOSH) showed that workers aged 29 and under were identified as the most involved in industrial accidents, particularly permanent and fatal disabilities. The increasing participation of women in the workforce has raised various genderrelated concerns about the impact of different occupational risk factors on men and women. The difference factor is that women prioritise more on safety practices because they have a high level of anxiety. The objective of this study is to investigate any potential differences in the level of workshop safety practices among students across genders. The population of this study comprised a total of 11,932 vocational colleges students and 378 students were selected as the research sample. Independent sample t-test was used to analyse the data. The results showed that the Levene's test value was $p>0.05$, thus the value of equal variance assumed was referred. Furthermore, the results also reported that $p=0.043(p<0.05)$, thus rejecting the first null hypothesis $(\mathrm{Ho})$. There was also difference in the total mean score of safety practices between male students $(\mu=3.66, S D=0.807)$ and female students $(\mu=3.95$, $\mathrm{SD}=0.954)$. Such finding is worrying as men are more dominant in technical careers and thus should invest more concern and effort in safety practices. In conclusion, having the knowledge and knowing the right tools and measures to prevent accidents must be learned by all individuals regardless of gender.
\end{abstract}

Keywords: Safety, Knowledge, Skill, Attitude

\section{Introduction}

The need for skilled workers in the use of modern equipment and machinery is necessary in line with the technological development of a country. Norhafizah (2014) stated that based on the Malaysian Vocational Education Transformation Program, the academic system in schools will be reduced and changed as well as the addition of industrial or practical practices for technical students to produce skilled and knowledgeable individuals to serve as high quality workers. Therefore, Technical and Vocational Education (TVE) is an education stream under the Ministry of Education that aims to provide ample opportunities for students to develop their potential and talents. The teaching and learning of TVE at Technical Secondary Schools 
(TSS) or Vocational Colleges (VC) is implemented via practical, either in the classroom or laboratory. Such practical component has important procedures that should be adhered for safety purposes to avoid any accidents.

Safety is an important factor as it is closely related to the individuals performing the work, the equipment used, and the work environment. It focuses not only on the individuals but also aspects such as the tools, machines, appliances, environment, management, and safety of other individuals involved (Fazreen, 2014). The safety aspect should be cultivated as early as possible to produce employees who are always sensitive to safety while doing a job, especially students from the skill stream (Mior, 2015). The negligence of the safety aspect will result in injury, loss of life, and property damage (Abd. Rashid, 2011). Therefore, the safety aspect needs to be practised efficiently and thoroughly throughout performing technical works.

The problem of safety negligence arises following the recent occurrence of numerous occupational accidents involving young adults. Abdul Rahim et al (2018) explained that accidents at the workplace are on the rise due to the lack of safety knowledge and proper safety training. Liu et al (2015) stated that although occupational accidents among young workers are not fatal, it confirms that occupational accidents are common among young workers.

\section{Problem Statement}

Generally, accidents that occur at the workplace or educational institutions are rarely exposed to the mass media to avoid any protracted issues and they are merely recorded in the accident record book of the respective organisations. Statistics by the National Institute of Safety and Health (NIOSH) in 2015 showed workers aged 29 and under were identified as the most involved in industrial accidents, especially permanent disability and death. In addition, a study by Yusof and Shamsul (2016) found that there was an accident that occurred at Temerloh Vocational College (TVC) in 2015, where a student enrolled in the building construction course had suffered a serious injury to his fingers due to negligence while using the machinery during practical works at the workshop. The interrogation results indicated that the accident occurred because the student did not follow the correct standard operating procedures while using the machine. Meanwhile, a study by Zainuddin and Azhar (2015) reported that VC students are often reported to experience accidents when handling tools and materials. The study further propounded that students' failure to observe the workshop rules was the main factor that led to the accidents.

Furthermore, the increasing participation of women in the workforce raises various gender-related questions about the impact of different occupational risk factors on men and women. Several studies have shown gender differences between employment and industry, although gender-sensitive approaches currently begin to gain its relevance within the technical field. Gyekye and Salminen (2011) reported significant differences in safety practices as both men and women have different traits especially in terms of alert nature. In addition, Meor and Syamsul (2017) also found a number of differences between men and women when practising safety measures at the workshop where women are more prone to observe safety practices due to their high level of anxiety. Therefore, the differences between these variables are influenced by the exposure to the level of danger in the career. Such issue thus motivates this research to investigate the differences in the level of workshop safety practices among students across genders. 


\section{Literature Review}

Safety practices generally involve the triadic elements of knowledge, skills, and attitudes. Thus, the Knowledge, Skill, and Attitude (KSA) model is widely used to measure the level of safety practices. The fundamental ground of the KSA model is formed by the Personal Professional Theory (De Bruijn, 2009). It posits that mastering the three elements of knowledge, skills, and attitude allows a student or employee to complete activities and chores that involve hard skills. According to De Bruijn (2009), these elements thus can be used to measure one's quality in mastering their jobs and responsibilities. Figure 2.1 shows the KSA Model that includes the three elements.

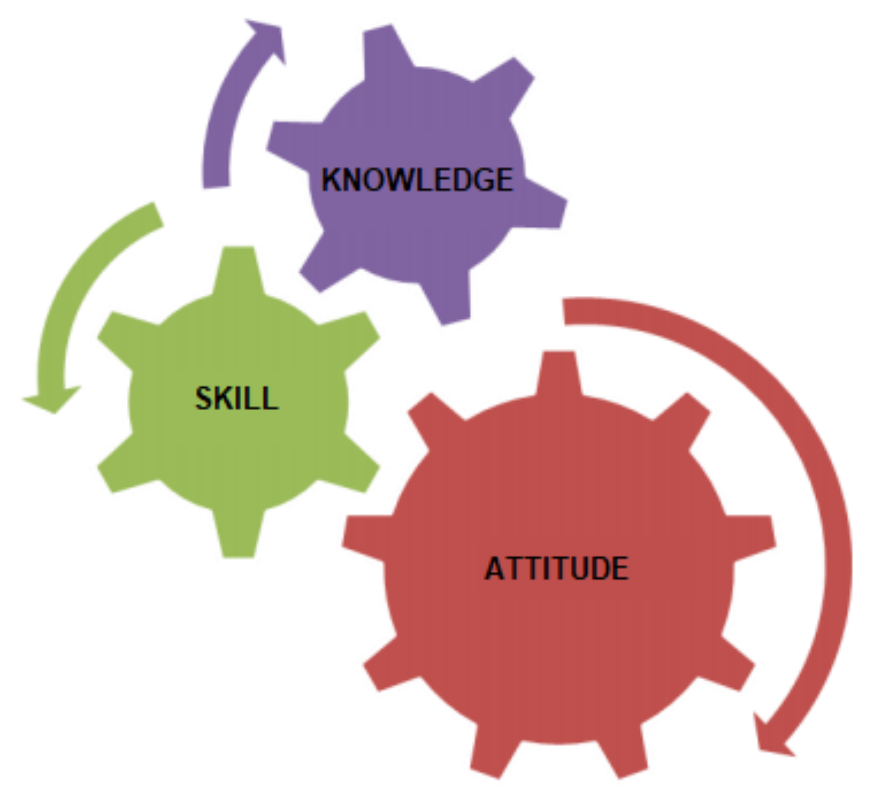

Figure 1-KSA Model

The knowledge element refers to an organised collection of information in the form of facts or procedures that can be applied to improve adequate job performance. Some information is applied directly to the execution of the function. This element can be measured using a set of questions with multiple choices of answers (Alade \& Omoruyi, 2018).

The skill element refers to the observable competence to perform a learned psychomotor action. Skills can be seen through the manual, verbal, or mental manipulation of data or objects. It can be measured through surveys using a five-point Likert scale or by administering performance tests where the quantity and quality of performance are tested within a specified time frame (Saris \& Gallhofer, 2017).

The attitude element refers to the strength to perform an activity. It describes the abilities demonstrated through activities or behaviours that are similar to those required at the workplace such as the ability to plan and organise works. In this regard, ability differs from talent and only has the potential to do the respective activities. It also refers to the competence to perform a visible behaviour or a behaviour that produces a visible product (Michalos et al., 2019). Thus, attitude can be measured through a survey study using a fivepoint Likert scale questionnaire. 


\section{Adapting the KSA Model in Studies}

The paradigm of learning carries a different interpretation in vocational education as opposed to the academic environment. Vermunt and Endedijk (2019) suggest several significant differences of learning processes within multiple learning environments. For example, students appear to be more active in organising their learning at the workplace component (skills learning) than during the school component (theory) in the educational program.

The KSA model revolves around competency development which emphasizes that students must not only acquire but also integrate knowledge, skills, and attitudes to achieve vocational competence (Esa, 2018). The general understanding of numerous definitions of mastery is that it consists integrated knowledge, skills, and attitudes that can be used to perform professional tasks successfully. Such factor prompted this research to adapt the KSA model as a guide in identifying the mastery of skill practice among students at school workshops. This is because these elements are capable of measuring students' efficiency in applying the project management process at school workshops.

Although many researchers have defined competency as the total of integrated knowledge, skills, and attitudes, it is argued that integration should be measured as a learning process and competence as a product of learning. This integration process later leads to certain levels of knowledge, skills and attitudes. While measuring competencies, we are able to assess the level of knowledge, skills, and attitudes when applied together to perform professional tasks. Furthermore, the triadic elements of knowledge, skills, and attitudes should be measured together (i.e., at the same time, within the same professional task) as they can be seen in the pattern of actions.

\section{Research Methodology}

The population of this study consisted of students from several VCs in Peninsular Malaysia with the Department of Electrical and Electronic Technology. The statistics showed a total of 11,932 students enrolling in certificate and diploma programs with 45 VCs that offer the Electrical and Electronic Technology course in Peninsular Malaysia. The sample size of this study was determined using the formula by Krejcie and Morgan (1996) based on the table of Determining Sample Size for Research Activities. It was determined that a population of 11,932 students required a minimum of 375 samples. However, a total of 378 samples were recruited that exceeded the minimum number required.

\section{Data Analysis}

Independent sample t-test analysis was used to investigate the differences in the level of workshop safety practices among students across genders. The analysis served the purpose of comparing two unrelated samples such as comparisons between demographics and variables. Chua (2009) posits that hypothesis testing requires the sig. value to determine whether there exist any differences between the tested variables. However, the value of Levene's test for equality of variances needs to be evaluated, where:

if sig. is $>0.05$, then the value of equal variance assumed should be referred. if sig. is $<0.05$, then the value of equal variance not assumed should be referred.

The hypothesis value was then decided based on the following assumptions: sig: $p>0.05$ then there is no difference.

sig: $p<0.05$ then there is a difference. 
The hypothesis of this study is as follows:

Ho: $\quad$ There were no significant differences in the mastery of workshop safety practices among students across gender.

Table 1 shows the analysis results in which the value of Levene's test is $p>0.05$, thus the value of equal variance assumed was referred. The results also show that $p=0.043$ ( $p$ $<0.05$ ), thus rejected the first null hypothesis, Ho, which predicted that there was no significant difference in the mastery of workshop safety practices among students across gender. This posits that there is a difference in the total mean score of safety practices among male students $3.66(\mu=3.66, S D=0.807)$ as compared to female students $(\mu=3.95, S D=$ 0.954).

Table 1 - Analysis of Differences in Safety Practices Across Gender

\begin{tabular}{|c|c|c|c|c|c|c|}
\hline \multirow[t]{2}{*}{ Variables } & \multirow{2}{*}{$\begin{array}{c}\text { Levene's } \\
\text { test } \\
\text { Sig. }\end{array}$} & \multicolumn{2}{|c|}{ Mean } & \multirow{2}{*}{$\begin{array}{c}\text { Mean } \\
\text { Difference }\end{array}$} & \multirow{2}{*}{$\begin{array}{c}\text { Statistics } \\
(\mathrm{t})\end{array}$} & \multirow[t]{2}{*}{$p$-value } \\
\hline & & Male & Female & & & \\
\hline Practices & 0.602 & $\begin{array}{c}3.66 \\
(S D= \\
0.807)\end{array}$ & $\begin{array}{c}3.95 \\
(S D= \\
0.954)\end{array}$ & $\begin{array}{c}-0.300 \\
(-0.581,- \\
0.009)\end{array}$ & -2.026 & 0.043 \\
\hline
\end{tabular}

Overall, the differences in the level of workshop safety practices among students across genders are significant. This was evident by the $p$-value where $p<0.05$ indicated $a$ significant difference in the mastery of workshop safety practices among students across genders.

\section{Conclusion and Recommendation}

The results of this study showed that there are significant differences in the mastery of workshop safety practices among students across genders. Beddoes and Panther (2015) stated that women are more likely to train safely and prioritise safety practices than men. In addition, the participation of female students and workers may be less in technical fields in line with the high rate of accident risks, yet they are more likely to perform better in handling safety practices. This is because their meticulous, alert, and caring nature enables women to maintain their performance while handling safety practices at workshops and the workplace. However, this should not happen because men are more dominant in technical careers and they also need to pay attention to safety practices. Therefore, having the knowledge and knowing the right tools and measures to prevent accidents must be learned by all individuals regardless of gender.

Workshop safety is an aspect that should be the main focus in doing practical works at workshops. This should be emphasised not only when doing practical works but at any time when students are within the workshop perimeter of a workshop. Safety should be viewed as a habit or a form of positive attitude that will never be nurtured unless regarded as a priority. Such safety aspect should be cultivated across all levels regardless of gender.

This study is limited to the Electrical and Electronic Technology course only. Studies involving the aspects of knowledge, skills, and attitudes need to be further extended to other courses offered in VCs especially those related to the industries with high accident statistics. This is because each of these aspects has its respective importance and can only be nurtured effectively in practice by combining all three aspects to the maximum. In addition, it is also 
recommended for future studies to use other theories or models related to work safety. The widespread use of theories and models can be applied to various other fields in the future.

The findings of this study are hoped to contribute and serve as a guide especially for related institutions and industries to improve the instruments used in meeting the criteria set by the stakeholders to the students and employees involved. Besides, the institution and organisation can show the important of safety start from the minute student or employee walk through the doors for and they should know that safety is one of your organization's central values. This can be done by including safety reminders and training in all steps of the hiring and onboarding processes as well as following through with them during every workday.

\section{Correspondent Author}

Nurul Nazirah Mohd Imam Ma'arof

Fakulti Teknikal dan Vokasional Universiti Pendidikan Sultan Idris

Email: nnazirah@ftv.upsi.edu.my

\section{References}

Abd. Rashid. (2011). The Relationship Between Effective Management In Terms Of Laboratory Manager Readiness With Improved Laboratory Safety Features. Master Project Report, Universiti Tun Hussein Onn Malaysia, UTHM Press.

Abdul Rahim, A. H., Zaimi, M. A., \& Bachan S. (2018). Causes of Accident at Construction Sites. Master Project Report, Universiti Teknologi Malaysia, UTM Press.

Alade, O. M., \& Omoruyi, I. V. (2014). Table Of Specification And Its Relevance In Educational Development Assessment. European Journal of Educational and Development Psychology. 2(1), 1-17

Beddoes, K., \& Panther, G. (2015). Workshop: Understanding Gender in Teamwork to Increase the Numbers of Women in Engineering.

Chua, Y. P. (2009) Statistik Penyelidikan Lanjutan Ujian Regresi, Analisis Faktor dan Ujian SEM. McGraw-Hill Malaysia, 2009.

De Bruijn, E. (2009). Integrating knowledge, skills and attitudes: Conceptualising learning processes towards vocational competence. Educational Research Review.

Esa, N. (2018). Environmental knowledge, attitude and practices of student teachers. International Research in Geographical and Environmental Education. https://doi.org/10.1080/10382040903545534

Fazreen, S. (2014). Awareness of Safety Practices Among Students in UTHM Engineering Laboratory. Master Project Report, Universiti Tun Hussein Onn Malaysia, UTHM Press.

Gyekye, S., \& Salminen, S. (2011). Organizational Safety Climate: Impact Of Gender On Perception Of Workplace Safety. Perspectives in Psychology Research. 61-77.

Krejcie, R. V., Morgan, \& W. D. (1996). Determining sample Size for Research Activities, Educational and Psychological Measurement. International Journal of Employment Studies, 18 (1), 89-123. Facilities Management: Research Directions : RICS Books.

Liu, X., Huang, G., Huang, H., Wang, S., Xiao, Y., \& Chen, W. (2015). Safety climate, safety behavior, and worker injuries in the Chinese manufacturing industry. Safety Science. https://doi.org/10.1016/j.ssci.2015.04.023

Meor, I. K. \& Syamsul, A. M. K. (2017). Level of Students' Awareness of Rules and Safety in Science Laboratories. Master Project Report, Universiti Teknologi Malaysia, UTM Press. 
Michalos, A., Creech, H., McDonald, C., \& Kahkle, M. H. (2019). Measuring knowledge, attitudes and behaviours towards sustainable development: Two exploratory studies. International Institute of Sustainable Development. https://doi.org/http://dx.doi.org/10.1530/EDM-16-0015

Mior, M. I. (2015). Study of Students' Perceptions on Safety Practices of Civil Engineering Workshop (Timber) Faculty of Engineering Technology. Master Project Report, Universiti Tun Hussein Onn Malaysia, UTHM Press.

National Institute of Occupational Safety and Health. (2015). Data and Statistics: Traumatic Occupational Injuries. NIOSH Report.

Norhafizah, J. (2014). Tendency of Academically Excellent Students Towards PTV Field Selection. Master Project Report, Universiti Tun Hussein Onn Malaysia, UTHM Press.

Saris, W. E., \& Gallhofer, I. N. (2017). Design, evaluation, and analysis of questionnaires for survey research. In Design, Evaluation, and Analysis of Questionnaires for Survey Research. https://doi.org/10.1002/9780470165195

Vermunt, J. D., \& Endedijk, M. D. (2011). Patterns in teacher learning in different phases of the professional career. Learning and Individual Differences. https://doi.org/10.1016/j.lindif.2010.11.019

Yusof, B., \& Shamsul, K. (2016). Level of Mastery of Safety Practices of Life Skills Workshop Among Form Four Students in Pontian, Johor. Master Project Report, Universiti Teknologi Malaysia, UTM Press.

Zainuddin \& Azhar, K. Y. (2015). Workshop Safety Practices Among Form 3 Life Skills Stream Students. Master Project Report, Universiti Teknologi Malaysia, UTM Press. 